\title{
ASSESSMENT OF THE ENVIRONMENTAL SENSITIVITY TO DESERTIFICATION IN RELATION TO LAND PRODUCTIVITY OF SOME SOILS AT WEST EDFU, EGYPT \\ Moamen M. EI Kady ${ }^{1}$ and Yasser A. Sayed ${ }^{2}$ \\ ${ }^{1}$ Department of Pedology, Desert Research Centre, El-Matariya 11753, Cairo, Egypt \\ ${ }^{2}$ Soils and Water Sci. Dept., Fac. Agric., Al-Azhar Univ., Assiut, Egypt \\ Corresponding author [e-mail: moamen.elkady@yahoo.com]
}

Key Words: Desertification assessment, Desertification sensitivity, Soil Quality Index, Vegetation Quality Index, Climate Quality Index, Edfu, Egypt

\section{ABSTACT}

Egypt is one of the territories that have been suffering from desertification and its unfavourable impact on socio-economy, food security, and gregarious stability. Thus, one of the main activities of Desert Research Centre is combating desertification in Egypt by assessing the sensitivity of the ecosystems to desertification and degradation vulnerability of land for resources conservation. Therefore, this paper aimed at appraising the environmental sensitivity to desertification in relation to land productivity of some soils at west Edfu, Egypt using the Desertification Sensitivity Index (DSI). The research area lies between $24^{\circ} 54^{\prime} 00^{\prime \prime}$ to $24^{\circ} 57^{\prime} 00^{\prime \prime} \mathrm{N}$ and $32^{\circ} 43^{\prime} 30^{\prime \prime}$ to $32^{\circ} 49^{\prime} 30^{\prime \prime} \mathrm{E}$; $85 \mathrm{~km} 2$. The results showed that the studied area was characterized by moderate soil quality with weak vegetation and hyper-arid climatic quality indices. Based on DSI, the investigated site could be identified as a sensitive area to desertification; with average and poor land productivity classes of grades III, and IV, respectively. The evaluated area is requiring particular soil management practices for best agricultural use and combating desertification.

\section{INTRODUCTION}

Desertification is a crucial environmental, social and economic issue to several countries altogether parts of the globe, especially in dry lands which cover about $41 \%$ of the Earth's surface and affect $38 \%$ of the cosmopolitan population (Reynolds et al., 2007; Breckle et al., 2001). David and Nicholas (1994) identified desertification that it means land degradation in arid, semiarid and dry sub-humid areas resulting essentially from climatic variations and unfavourable human impact.

Assorted investigations (Khanamani, et. al., 2017; Tavares et al., 2015; Vasu et al., 2016) have been conducted to assess the environmental sensitivity to desertification and its impact on productive 
land in different regions of the Earth. These studies are greatly contributing to information related to the desertification process.

There are many factors that can contribute to desertification; these factors include soil, vegetation, climate, demographic and human activities, each of these factors has different variables determining it, (Gad and Lotfy, 2006). The most dominant degradation problems leading to desertification in arid regions like Egypt were represented in wind erosion and salinization (Glantz, 1977; Quintanilla, 1981; Zonn, 1981).

Gad and Lotfy, (2008) used remote sensing and GIS techniques in mapping the environmental sensitivity areas for desertification of Egyptian territory. They found that Egyptian territory is susceptible to very high-to-high desertification sensitivity, however the Nile Valley is moderately sensitive because of its vegetation cover. They concluded that action measures concerning to desertification appraisement are essential for the sustainable agricultural projects located in the desert oases, wadis and interference zone.

Soils in west Edfu are promising for land reclamation projects due to their location nearby the urban areas and availability of groundwater resources for crop irrigation (Abdalazem et. al., 2020). So, one of the important steps to improve the employment of its natural resources is assessment of this soils for desertification sensitivity as a necessary stage prior to the agricultural use.

Based on that, this paper aimed at assessing the environmental sensitivity to desertification in relation to land productivity of some soils at west Edfu, Egypt using the Desertification Sensitivity Index (DSI).

\section{MATERIALS AND METHODS}

\subsection{Study area location and general characteristics}

The study area is located in west Edfu, Aswan governorate-Egypt, which lies between latitudes $24^{\circ} 54^{\prime} 00^{\prime \prime}$ and $24^{\circ} 57^{\prime} 00^{\prime \prime} \mathrm{N}$ and longitudes $32^{\circ} 43^{\prime} 30^{\prime \prime}$ and 32 49'30"E, with an area about $85 \mathrm{~km}^{2}$, (Fig. 1). According to Egyptian Meteorological Authority (2011), the climatic regime is hot and characterized by moderate winter and very hot arid summer typically called a desert climate. There is almost no rainfall during the year (about $1 \mathrm{~mm}$ of precipitation). The average annual temperature is $26.8{ }^{\circ} \mathrm{C}$ in Edfu. The studied area could be classified as Hyperthermic temperature regime and Torric soil moisture regime (Soil Survey Staff, 2014).

Geologically, the Nubia formation of Cretaceous age (Issawi, 1981) which covers all the examined area and overlies the basement

rocks, is mainly composed of sand and sandstone with clay and shale intercalations of irregular thicknesses (Fig.2). El-Desoky and Sayed (2019) classified the research area into three geomorphologic units 
throughout interpreting satellite images and DTM techniques. These units are in the following; (i) Overflow basin, (ii) River terraces, and (iii) Decantation basin, Fig. (3).

\subsection{Soil sampling and laboratory analyses}

On the basis of geomorphological variation, seven soil profiles were selected, (Fig. 3) and described morphologically in accordance with norms of soil description, Soil Survey Manual (Soil Survey Division Staff 2012). Soil samples were collected and laboratory analyzed following the standard methods of Burt (2014).

\subsection{Land productivity appraisement}

The investigated area was appraised on basis of Riquier Land Productivity Index (RLPI) using the model produced by Riquier et al. (1970) into; (1) poor land productivity class (grade IV) which comprise the major part of the studied site, and (2) average land productivity class (grade III) which covers the rest of area, (El-Desoky and Sayed 2019), Table (1) and Fig. (4). Analytical data referred to that the studied soils were highly affected by degradation of salinization and alkalinization.

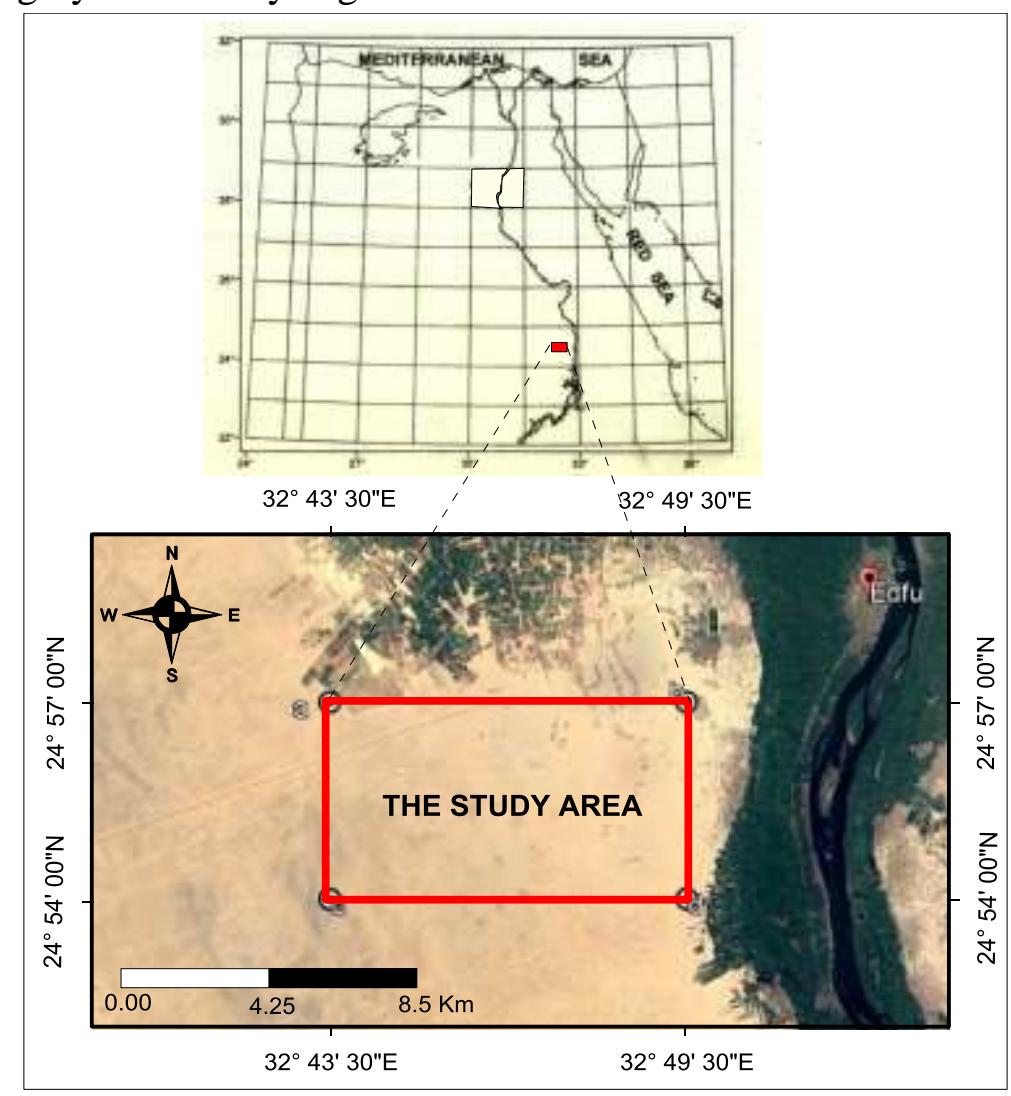

Fig. (1): Site of the studied area 

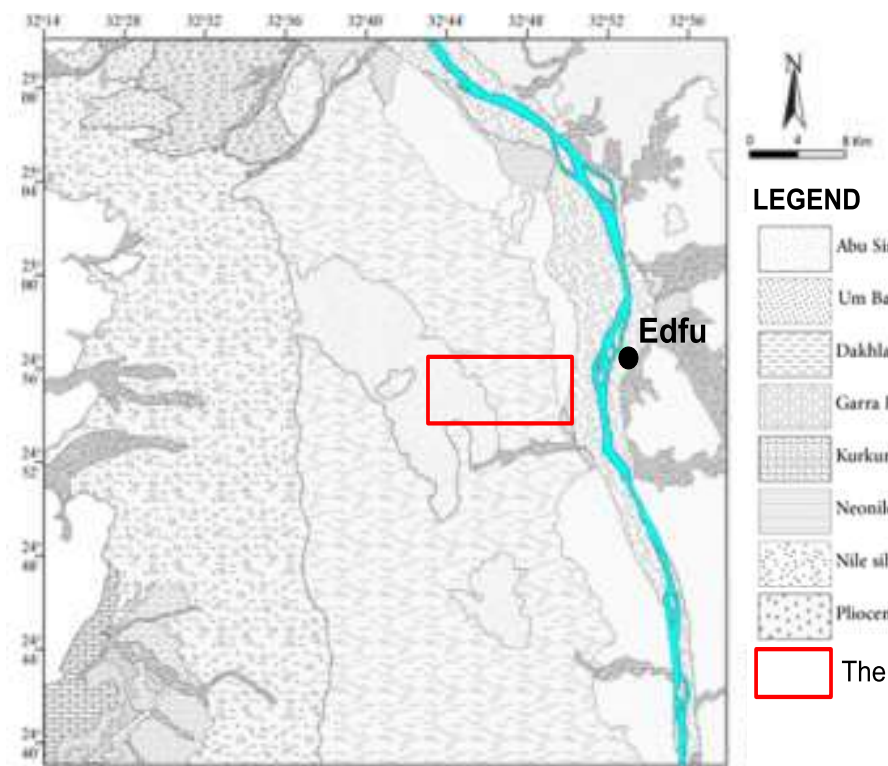

LEGEND

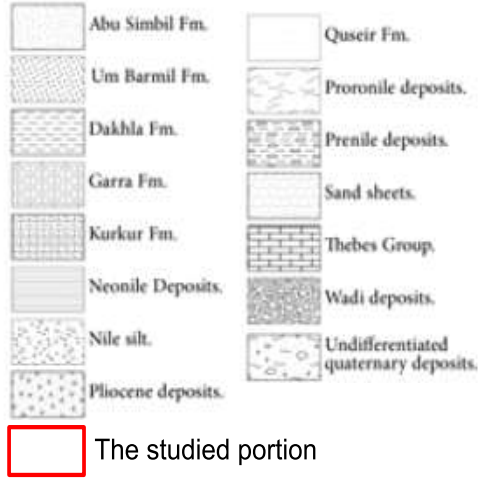

Fig. (2): Geology of the investigated portion, after Abdalazem et. al., (2020) and Issawi, (1981)

$32^{\circ} 45^{\circ} \mathrm{O}^{\circ \mathrm{E}} \quad 32^{\circ} 48^{\circ} \mathrm{O}^{\circ} \mathrm{E}$

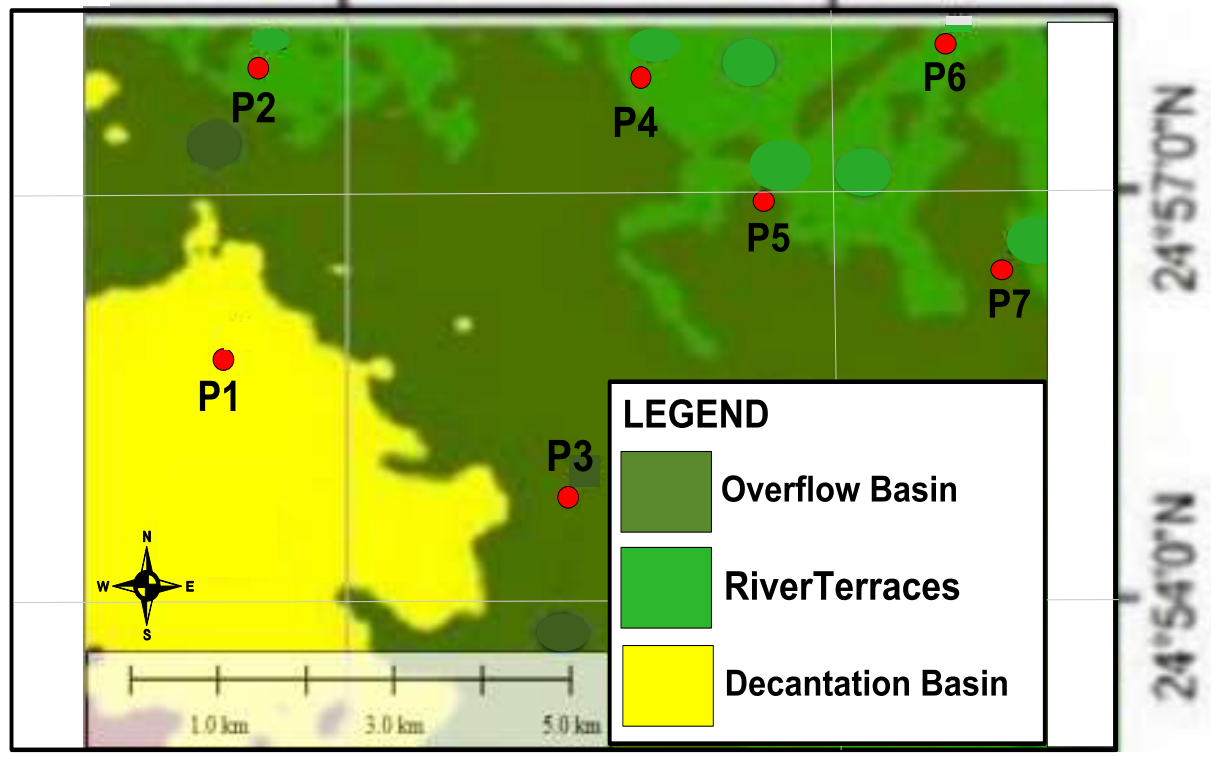

Fig. (3): Geomorphology of the studied area after El-Desoky and Sayed (2019), and locations of soil profiles 
Table (1) Soil properties of the studied area

\begin{tabular}{|c|c|c|c|c|c|c|c|c|c|c|c|}
\hline $\begin{array}{c}\text { Profile } \\
\text { No. }\end{array}$ & $\begin{array}{c}\text { Slope } \\
\%\end{array}$ & $\begin{array}{l}\text { Depth( } \\
\text { cm) }\end{array}$ & $\begin{array}{c}\text { Drainage } \\
\text { Status }\end{array}$ & Texture & $\begin{array}{c}\text { EC } \\
\mathrm{dS} / \mathrm{m}\end{array}$ & $\begin{array}{c}\text { pH } \\
(1: 25)\end{array}$ & $\begin{array}{c}\text { OM } \\
\%\end{array}$ & $\begin{array}{c}\text { CEC } \\
(\mathrm{cmol}(+) / \\
\mathrm{kg})\end{array}$ & $\begin{array}{c}\text { Gypsum } \\
\%\end{array}$ & $\begin{array}{c}\mathrm{CaCO}_{3} \\
\%\end{array}$ & $\begin{array}{c}\text { ESP } \\
\%\end{array}$ \\
\hline 1 & $0.5-1$ & 150 & $\begin{array}{l}\text { Poorly } \\
\text { drained }\end{array}$ & sg_scl & 57.7 & 7.8 & 0.52 & 20 & 1.84 & 10 & 19 \\
\hline 2 & $0.5-1$ & 150 & $\begin{array}{l}\text { Imperfectly } \\
\text { drained }\end{array}$ & sg_sl & 18.2 & 8.1 & 0.36 & 12 & 1.50 & 3 & 20 \\
\hline 3 & $0.5-1$ & 150 & $\begin{array}{l}\text { Imperfectly } \\
\text { drained }\end{array}$ & gsl & 8.8 & 8.4 & 0.22 & 10 & 0.48 & 1 & 25 \\
\hline 4 & $0.5-1$ & 150 & $\begin{array}{l}\text { Poorly } \\
\text { drained }\end{array}$ & sg_scl & 24.5 & 8.1 & 0.36 & 13 & 2.55 & 9 & 17 \\
\hline 5 & $0.5-1$ & 150 & $\begin{array}{l}\text { Imperfectly } \\
\text { drained }\end{array}$ & gsl & 161.9 & 7.9 & 0.56 & 13 & 3.87 & 1 & 19 \\
\hline 6 & $0.5-1$ & 150 & $\begin{array}{c}\text { Well } \\
\text { drained }\end{array}$ & gls & 54.8 & 8.4 & 0.36 & 9 & 1.97 & 1 & 18 \\
\hline 7 & $0.5-1$ & 150 & $\begin{array}{c}\text { Well } \\
\text { drained }\end{array}$ & sg_ls & 9.9 & 8.5 & 0.23 & 10 & 0.65 & 1 & 19 \\
\hline
\end{tabular}

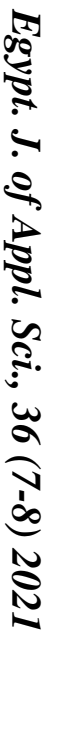

Abbreviations

Texture:

sg_scl (slightly gravelly sandy clay loam; sg_sl (Slightly gravelly sandy loam); gsl (gravelly sandy loam); gls (gravelly loamy sand); sg_ls (slightly gravelly loamy sand)

$\mathrm{EC}$ Electrical Conductivity

$\mathrm{pH}(1: 25)$

OM:

$\mathrm{pH}$ measured in soil solution with ( $1 \mathrm{~g}$ soil to $25 \mathrm{ml}$ water)

Cation Exchange Capacity

$\mathrm{CaCO}_{3}$. Calcium Carbonate

ESP: $\quad$ Exchangeable Sodium Percentage 


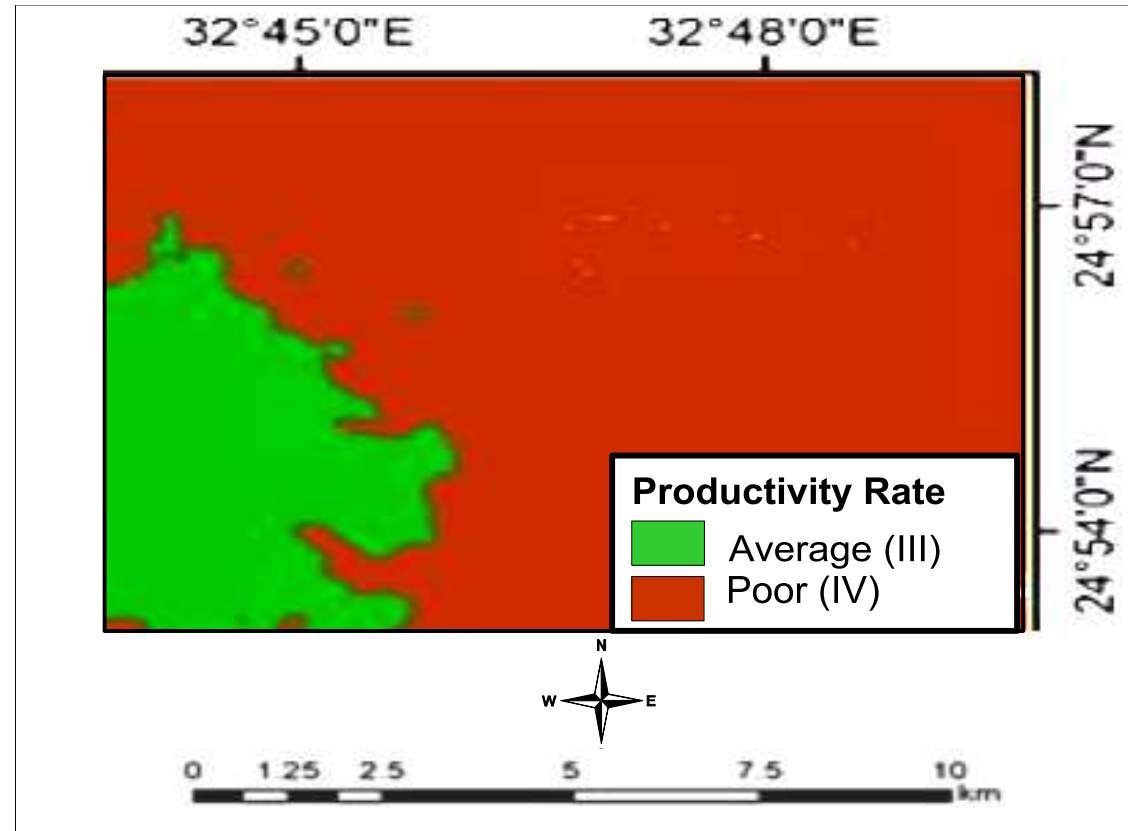

Fig. (4): Land productivity classes of the studied area after El-Desoky and Sayed (2019)

\subsection{Assessment of the environmental sensitivity to desertification}

The environmental sensitivity to desertification of the investigated portion was evaluated using the Desertification Sensitivity Index (DSI). The DSI was calculated according to the equation adopted from MEDALLUS methodology, Basso et al., (2000) and the investigation which is conducted by Gad and Lotfy, (2008) as follows; DSI $=\left(\mathrm{SQI}^{*} \mathrm{CQI}^{*} \mathrm{VQI}\right)^{1 / 3}$

Where SQI is the soil quality index, CQI is the climate quality index and VQI is the vegetation quality index. The SQI is based on rating the parent material, slope, soil texture, and soil depth. The SQI was calculated according to the following equation,

$\mathrm{SQI}=(I p * I t * I d * I s)^{1 / 4}$

Where, Ip index of parent material, It index of soil texture, Id index of soil depth, Is index of slope gradient).

The VQI is computed on basis of rating three categories (i.e. erosion protection, drought resistance and plant cover). It was calculated according the following equation,

$\mathrm{VQI}=\left(I_{E p} * I_{D r} * I_{V c}\right)^{1 / 3}$ 
Where: $I_{E p}$ index of erosion protection, $I_{D r}$ index of drought resistance and $I_{V c}$ index of vegetation cover.

The CQI is appraised based on the aridity index, derived from values of annual rainfall and potential evapo-transpiration which were extracted from Egyptian Meteorological Authority (2011). The CQI was calculated according to the following equation, $\mathrm{CQI}=P / P E T$

Where: $P$ is average annual precipitation and $P E T$ is average annual potential evapo- transpiration. The Ranges and classes of DSI are illustrated in Table (2).

Table 2: Ranges and classes of desertification sensitivity index (DSI)

\begin{tabular}{|c|c|c|}
\hline Classes & DSI & Description \\
\hline \hline 1 & $>1.2$ & $\begin{array}{c}\text { Non affected areas or very low sensitive areas } \\
\text { to desertification }\end{array}$ \\
\hline 2 & $1.2<\mathrm{DSI}<1.3$ & Low sensitive areas to desertification \\
\hline 3 & $1.3<\mathrm{DSI}<1.4$ & Medium sensitive areas to desertification \\
\hline 4 & $1.3>\mathrm{DSI}<1.6$ & Sensitive areas to desertification \\
\hline
\end{tabular}

\section{RESULTS AND DISCUSSION}

The Soil Quality Index (SQI) was evaluated based upon the indices of parent material, soil depth, soil texture class and slope. The geologic map was used to deduce the nature of parent material, where the results showed that the studied site is originated from soft to friable (i.e calcareous clay, clay, sandy formation, and alluvium materials). Field and laboratory analyses were used for assessing the other indices of soil depth, soil texture, and slope. The considered soils were deep $(150 \mathrm{~cm})$ and based of that, the soil depth index has nominated to take the score of "1". Soil texture index was classified as either "not very light to average" or "fine to average" where it has got a score (1-1.66). The slope gradient index showed homogeneous values and has given a score " 1 ". Calculating the soil quality index (1.19-1.35), revealed that the studied soils are characterized by moderate soil quality, (Table 3).

The vegetation plays an essential role in erosion protection, drought resistance and soil capacity protection, (Gad and Lotfy, 2008). Based on the previous parameters, the VQI was appraised and showed that the estimated soils had weak vegetation quality index and sensitive to desertification, (Table 4). This is coming back to the Saharan vegetation which covers the investigated area with less than $40 \%$ and provides a low capacity to increase kinetic energy caused by the impact of soil erosion driving forces. 
Table 3: Soil quality index (SQI) in the investigated area

\begin{tabular}{|c|c|c|c|c|c|}
\hline Profile No. & Ip & It & Id & Is & SQI \\
\hline \hline 1 & 2 & 1.66 & 1 & 1 & 1.35 \\
\hline 2 & 2 & 1 & 1 & 1 & 1.19 \\
\hline 3 & 2 & 1 & 1 & 1 & 1.19 \\
\hline 4 & 2 & 1.66 & 1 & 1 & 1.35 \\
\hline 5 & 2 & 1 & 1 & 1 & 1.19 \\
\hline 6 & 2 & 1 & 1 & 1 & 1.19 \\
\hline 7 & 2 & 1 & 1 & 1 & 1.19 \\
\hline
\end{tabular}

Abbreviations: Ip-parent material index; It-soil texture index; Id-soil depth index; Isslope gradient index; SQI-soil quality index

Data of climate (i.e. rainfall and evapo-transpiration) related to the studied area referred to that precipitation ranged between 0 to 1 percent annually while the average annual potential evapo-transpiration is relatively high. This qualified the research area to be affected by the hyper-arid climatic conditions. Accordingly, climatic quality index (CQI) has got a score equal to 2, (Table 4).

Table 4: Vegetation and climate quality indices in the investigated area

\begin{tabular}{|c|c|c|c|c||c|c|}
\hline Profile No. & $\mathbf{I}_{\mathbf{E p}}$ & $\mathbf{I}_{\mathbf{D r}}$ & $\mathbf{I}_{\mathbf{V} \mathbf{c}}$ & $\mathbf{V Q I}$ & P/PET & CQI \\
\hline \hline 1 & 2 & 1.66 & 1 & 1.49 & & \\
\hline 2 & 2 & 1.66 & 1 & 1.49 & 0.04 & 2 \\
\hline 3 & 2 & 1.66 & 1 & 1.49 & 0.04 & 2 \\
\hline 4 & 2 & 1.66 & 1 & 1.49 & 0.04 & 2 \\
\hline 5 & 2 & 1.66 & 1 & 1.49 & 0.04 & 2 \\
\hline 6 & 2 & 1.66 & 1 & 1.49 & 0.04 & 2 \\
\hline 7 & 2 & 1.66 & 1 & 1.49 & 0.04 & 2 \\
\hline
\end{tabular}

Abbreviations: $\mathrm{I}_{\mathrm{Ep}}$-index of erosion protection; $\mathrm{I}_{\mathrm{Dr}^{-}}$index of drought resistance; $\mathrm{I}_{\mathrm{Vc}^{-}}$ index of vegetation cover; VQI-vegetation quality index; P/PETprecipitation/potential evapo-transpiration; CQI-climate quality index

The three former indices were driven jointly for the appeasement of the environmentally sensitive areas (ESA's) to desertification. On basis of the calculated Desertification Sensitivity Index (DSI), the investigated site could be classified as sensitive area to desertification, (Table 5) with average and poor land productivity classes of grades III, and IV, respectively. This means that the research area needs to particular soil management practices for best agricultural use and combating desertification, can be summarized in the following; 
(1) Designing recent irrigation systems along with agricultural drainage.

(2) Increase organic matter inputs.

(3) Use cover crops.

(4) Rotate crops.

(5) Manage Nutrients.

(6) Adding the agricultural gypsum.

Table 5: Desertification Sensitivity Index (DSI) in the investigated area

\begin{tabular}{|c|c|c|c||c|}
\hline Profile No. & SQI & VQI & CQI & DSI \\
\hline \hline 1 & 1.35 & 1.49 & 2 & 1.58 \\
\hline 2 & 1.19 & 1.49 & 2 & 1.52 \\
\hline 3 & 1.19 & 1.49 & 2 & 1.52 \\
\hline 4 & 1.35 & 1.49 & 2 & 1.58 \\
\hline 5 & 1.19 & 1.49 & 2 & 1.52 \\
\hline 6 & 1.19 & 1.49 & 2 & 1.52 \\
\hline 7 & 1.19 & 1.49 & 2 & 1.52 \\
\hline
\end{tabular}

\section{CONCLUSIONS}

This study aimed at assessing the environmental sensitivity to desertification in relation to land productivity of some soils at west Edfu, Egypt using the Desertification Sensitivity Index (DSI). In conclusion, the studied site had DSI varying from 1.52 to 1.58 , indicating a sensitive area to desertification with average (III), and poor (IV) land productivity classes. This referring to that the research area needs particular soil management practices and applied safety environmentally techniques for best agricultural use and reducing the sensitivity for desertification.

\section{REFERENCES}

Abdalazem, A.H. ; H.M. Khozyem ; M.A. Gamee ; A.A.M. Awad and A.G. Mohamed (2020): Assessment of some Physical and Chemical Properties of Soils in West Edfu Area, Aswan Governorate, Egypt. Assiut J. Agric. Sci., 51(1):150-170.

Basso, F. ; E. Bove ; S. Dumontet ; A. Ferrara ; M. Pisante ; G. Quaranta and M. Taberner (2000). Evaluating Environmental Sensitivity at the basin scale through the use of Geographic Information Systems and Remote Sensed data: an example covering the Agri basin (southern Italy), Catena, 40: 19-35.

Breckle S.W. ; M. Veste and W. Wucherer (2001): Sustainable Land Use in Deserts. 
Burt, Rebecea (2014): Soil Survey Field and laboratory methods manual. Soil Survey Investigation Report No. 51, Ver. 2.0, Kellegg Soil Survey Laboratory, National Soil Survey Center, Natural Resources Conservation Service, USDA, Lincoln, Nebraska.

David, S.G.T. and J.M. Nicholas (1994). Desertification Exploding the Myth. A book published in Wiley, New York.

Egyptian Meteorological Authority, (2011). The normal's for Aswan station, (1960- 2010), Ministry of Civil Aviation, Cairo, Egypt.

El-Desoky, A. I., and Y. A. Sayed, 2019. Land Productivity Evaluation of Edfu Area, Aswan, Egypt, Using Remote Sensing and Geographic Information System Techniques. Menoufia J. Soil Sci., 4: $89-100$.

Gad, A. and I. Lotfy (2008): Use of remote sensing and GIS in mapping the environmental sensitivity areas for desertification of Egyptian territory. eEarth Discussions is the access reviewed discussion forum of Earth., 3: 41-85.

Gad, A. and I. Lotfy (2006): Use of remote sensing and GIS in mapping the environmental sensitivity areas for desertification of Egyptian territory. In: Proceedings of the Second International Conference on Water Resources and Arid Environment 2006, Riyadh, Kingdom of Saudi Arabia, 26-29 November 2006.

Glantz, M. H. (1977): Desertification: Environmental Degradation in and around Arid Lands, Boulder, Westview Press.

Issawi, B. (1981): Geology of the southwestern Desert of Egypt, Geol. Surv. Egypt. Cairo XI: 57-66.

Khanamani, A. ; H. Fathizad ; H. Karimi and S. Shojaei (2017): Assessing desertification by using soil indices. Arabian Journal of Geosciences, 10: 1-10.

Quintanilla, E.G. (1981): Regional aspects of desertification in Peru, in: Combating Desertification through Integrated Development, UNEP/UNEPCOM International Scientific Symposium, Abstract of Papers, Tashkent, USSR, 114-115.

Reynolds, J.F. ; D.M. Stafford Smith ; E.F. Lambin ; B.L. Turner ; M. Mortimore ; S.P.J. Batterbury and B. Walker (2007): Global desertification: Building a science for dryland development. Science, 316(5826): 847-851.

Riquier, J. ; D.L. Bramao and J.P. Cornet (1970): A new system of soil appraisal in terms of actual and potential productivity. FAO, Soil Resources, Development and Conservation Service, Land and Water Development Division. FAO, Rome.

Soil Survey Division Staff (2012): Soil survey manual. Soil Conservation Service. U.S. Department of Agriculture Handbook 18. 
Soil Survey Staff, (2014): Keys to soil taxonomy.12th ed. United States Department of Agriculture, Natural Resources Conservation Service, Washington, DC.

Tavares, J.D.P. ; I. Baptista ; A.J.D. Ferreira ; P. Amiotte-Suchet ; C. Coelho ; S. Gomes and L. Varela (2015). Assessment and mapping the sensitive areas to desertification in an insular Sahelian mountain region case study of the Ribeira Seca Watershed, Santiago Island, Cabo Verde. Catena, 128: 214-223.

Vasu, D. ; S.K. Singh ; S.K. Ray ; V.P. Duraisami ; P. Tiwary ; P. Chandran and S.G. Anantwar (2016): Soil quality index (SQI) as a tool to evaluate crop productivity in semiarid Deccan Plateau, India. Geoderma, 282: 70-79.

Zonn, I.S. (1981): USSR/UNEP Projects to Combat Desertification, Moscow Centre of International Projects GKNT, 33, 1981. World Climatelogical organization (WMO): Climate and Land Degradation, WMO No. 989, ISBN 92-63-10989-3, 2005.

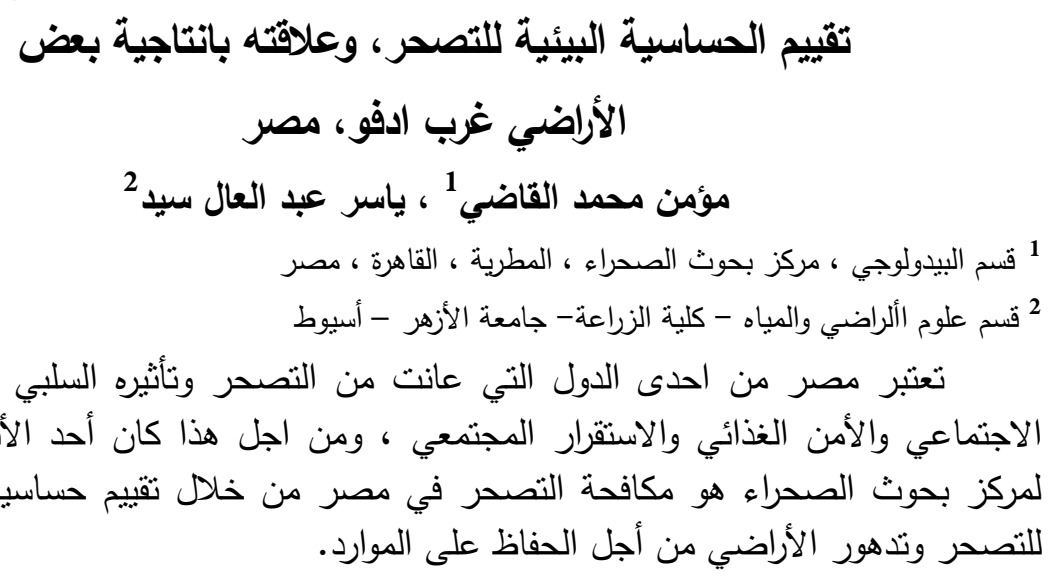

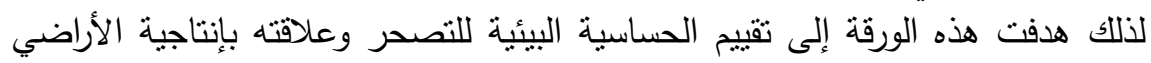

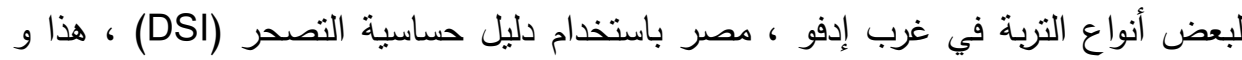

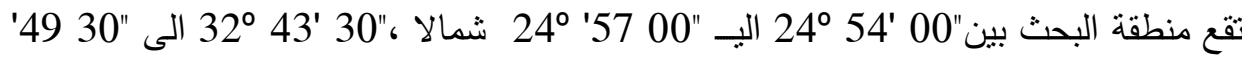
$32^{\circ}$

وقد أظهرت النتائج أن المنطقة المدروسة تميزت بمؤشر جودة تربة من الدرجة المعتدلة

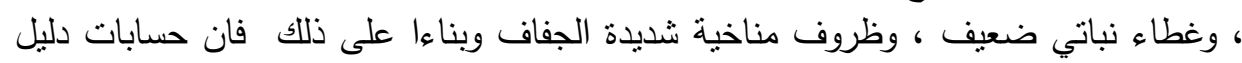

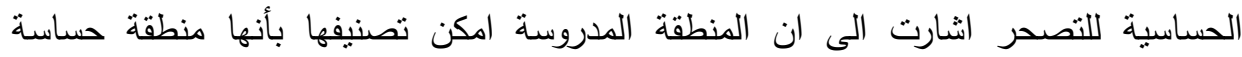

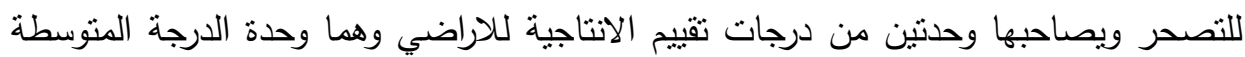

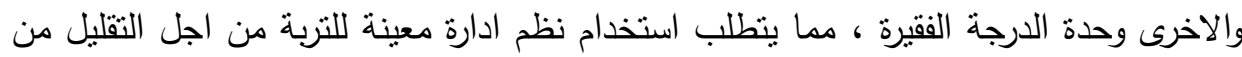
اخطار التصحر بها وافضل استغلال مدكن للزراعة. 